\title{
How Job Satisfaction Factors Affects Components of Organizational Commitment: Study on Employees of Star Hotels in Eritrea
}

\author{
Saba Habtom Araya and Dr. Ma Haiyan \\ Corresponding Author \\ School of Economics and Management \\ China University of Geosciences \\ Wuhan 388 Lu Mo Lu, Hong Shang District, Wuhan, Hubei 430047, P.R. China \\ Corresponding email: sabi656@yahoo.com
}

Doi:10.5296/ijhrs.v5i4.8770 URL: http://dx.doi.org/10.5296/ijhrs.v5i4.8770

\begin{abstract}
This study focused on how job satisfaction factors affects components of organizational commitment among the basic employees of star hotels in Eritrea. Besides, the impact of control variables on the relationship between job satisfaction factors and components of organizational commitment were assessed. Job Satisfaction Survey (JSS) by Spector and Organizational Commitment Questionnaire (OCQ) by Mayer and Allen were used to measure the respondents' job satisfaction and organizational commitment.

Pearson Correlation analysis was done to identify the relationship between the independent variables and dependent variable. The results indicates that there is significant relationship between pay satisfaction, satisfaction with promotion, satisfaction with nature of work and satisfaction with communication in the organization and employees' organizational commitment, in which each variables is significant at $p=.000$. Nevertheless, satisfaction with supervision and co-workers found to be insignificant to contribute to basic employees' commitment with $p>0.05$. With regard to the degree and direction of relationship, satisfaction with pay has strong and positive relationship, satisfaction with promotion, nature of work and communication possesses a moderate positive relationship with organizational commitment.

To identify whether control variables have impact on the relationship $b / n$ job satisfaction factors and components of organizational commitment, a hierarchical stepwise multiple regressions was examined. Though the correlation analysis illustrated that pay, promotion, nature of work and communication can contributes to the basic employees' affective, continuance and normative commitment, but with the presence of the control variables the result appeared differently. On the presence of control variables, pay, promotion, supervision and communication can contributes to the employees' affective commitment; pay and
\end{abstract}


promotion can contributes to the employees' continuance commitment and only pay can contributes to the employees' normative commitment.

Keywords: Job Satisfaction, Organizational Commitment, Star Hotels, Eritrea

\section{Introduction}

The study of behavior in an organization stands as a pillar driving to promote the human resource management practices in which this or that way contributes to the organization's success. Viewing employees as the primary source of competitive advantage, employee job satisfaction and ascertaining their commitment significantly influence the overall organizational performance as well as employee's job behavior and feeling. Of great relevance, job satisfaction and commitment are a vital issues in any organization in a sense that both affects a wide range of behaviors and contributes to workers' well-being, (Drakopoulos and Grimani 2011). Employees are the key connector in the relationships between an organization and its customers and hence today business organizations are more concerned in building their employees' commitment as employees commitment results in work efficiency and greater outputs which every organization desire for (Warsi, Fatima et al. 2009).In order to satisfy their customers, organizations supposed to provide high service quality which can be achieved through satisfied and committed employees (Kabir and Parvin 2011).

\section{Literature Review and Hypothesis}

\subsection{Job Satisfaction}

A well-know and a popular research theme, Job satisfaction was defined in several ways. Regardless the number of researches done, none of the researchers agree on a universal definition of job satisfaction. A simple definition of job satisfactions is given by (Spector 1997) as the extent to which people like or dislike their job". Job satisfaction refers to the general attitude of employees towards their jobs. When the attitude of an employee towards his or her job is positive, there exists job satisfaction but dissatisfaction exists when the attitude is negative (Armstrong and Taylor 2014). An employee has higher or lower levels of job satisfaction because they have lower or higher expectations, to a great extent job satisfaction depends on employees' attitude and expectations, shortly, job satisfaction is a sense of comfort and positive experience that an employee have related to his job (Bakotić and Babić 2013).

\subsection{Factors of Job Satisfaction Pay}

Pay refers to the amount of money that an employee receives for a particular job or function in an organization. It has a fundamental role in attracting, retaining and motivating employees. Researches such as (Hom and Griffeth 1995) and (Cohen-Charash and Spector 2001)demonstrated that pay satisfaction positively related to employee commitment. Besides, 
based on research result (Tang and Chiu 2003)suggested that employees having high level of pay satisfaction are also highly committed to the organization. A study among employed in the IT environment found that pay satisfaction is significantly and positively related to affective and normative commitment (Lumley, Coetzee et al. 2011).

H1: Pay will have significant positive relationship with affective, continuance and normative commitment.

\section{Promotion}

Promotion refers to upward movement in current job leading to greater responsibilities, higher status and better salary. Employees who believe a promotion is possible in the near future tend to have higher job satisfaction and their intension to quit their job is low (Kosteas 2011). A promotion program in an organization is a critical component for employees' encouragement, loyalty and satisfaction. (Teclemichael Tessema and Soeters 2006), (Mustapha and Zakaria 2013), (Bhamani) and (Danish and Usman 2010) research results demonstrated that promotion practices have positive relationship with perceived performance of employees, and job satisfaction and employees' work motive respectively. Moreover,(Gaertner and Nollen 1989) and (Chughtai and Zafar 2006) results proved that promotion opportunities is positively related to employees commitment and they suggested that employees who have been promoted tends to be more committed.(Mohd 2003) found that promotion system to be the most essential factor influencing an employee's commitment level.

H2: Promotion will have significant positive relationship with affective, continuance and normative commitment.

\section{Supervision}

Effective supervision is a foundation of a successful organization. Supervisors should take actions to improve their workers such as providing strong leadership and mentoring for staff members, building working conditions that are conducive and provide challenging and stimulating work assignments (Voon, Lo et al. 2011). A meta-analysis study by (Barak, Travis et al. 2009) summarized that all the supervisory dimensions (task assistance, social and emotional supervisory support, and supervisory interpersonal interaction) are found to be positively and statistically significantly related to beneficial outcomes for workers. In addition, (Chughtai and Zafar 2006) results stated that satisfaction with supervision is likely to be an important predictor of organizational commitment, and argue that when the supervisor takes cares about the employees, this will be an alarm that informs employees that organization cares about them and supports them, which in turn is lead to higher levels of organizational commitment.

H3: Supervision will have significant positive relationship with affective, continuance and normative commitment.

\section{Co-workers}

Positive relationships with co-workers can make the work environment more attractive and 
increase job satisfaction. If workers built a strong relationship among them it opens ways for cooperation among themselves to accomplish their work effectively. A recent study by (Sypniewska 2014) found that the relationship between co-workers to be the second most important factor that influence employees job satisfaction. The more healthy friendship and supportive manners among employees, the more will be their satisfaction and commitment (Alshitri 2013). Co-worker support is able to increase or decrease an employees' job satisfaction, which consequently effects intention to quit. A research result among service industry in Oman shows that satisfaction with co-workers is positively related to employees organizational commitment (Azeem 2010). Besides, (Lumley, Coetzee et al. 2011)suggested that pay, nature of work and co-worker relationships need to be congruent with employees' own needs, making them feel affectively committed to their employer and resulting in improved retention.

H4: Co-workers will have significant positive relationship with affective, continuance and normative commitment.

\section{Nature of work}

Robbins et al. (2003) defined nature of work as the extent to which the job provides the individual with stimulating tasks, opportunities for learning and personal growth, and the chance to be responsible and accountable for results". Nature of job that provides opportunity to be creative, use number of skills and work independently has a significant positive influence to employees' job satisfaction.(Malik, Nawab et al. 2010) found that nature of work, salary satisfaction and quality supervision are significant predictors of organizational commitment.

H5: Nature of work will have significant positive relationship with affective, continuance and normative commitment.

\section{Communication}

As (Tourani and Sadegh 2012) cited, Dwyer (2005) defined communication as the process whereby people within an organization give and receive messages". A lack of communication in an organization can lead to poor employees' performance as communication is a root that feeds employees with appropriate information which is functional for the accomplishments of their works. Effective communication between coworkers and with supervisors significantly associated with employee's job satisfaction (Saleem, Majeed et al. 2013). Moreover, from the standardized multiple regression result (YAU 2013) reported that communication satisfaction explains 74.7 percent of the variance in the organizational commitment and hence communication satisfaction is viewed as a stronger variable to impact organizational commitment.

H6: Communication will have significant positive relationship with affective, continuance and normative commitment.

\subsection{Organizational Commitment}

According to (O'Reilly III 1989), organizational commitment is defined as an individual's 
psychological bond to the organization, including a sense of job involvement, loyalty and belief in the values of the organization" in this respect employee commitment is viewed as the employee's enthusiasm toward the achievement of the organizational goals. Similarly, (Meyer and Allen 1991) definition as a psychological state that characterizes the employee's relationship with the organization, and has implications for the decision to continue membership in the organization".

A popular and extensively used organizational commitment model is a Three-Component model developed by Allen and Meyer. A three- component model of organizational commitment manifested three distinct components of commitment, namely affective commitment, Continuance commitment and normative commitment. Those three different components are distinguished based on the employees' attitudinal commitment. Employees with strong affective commitment remain because they want to, those with strong continuance commitment because they need to, and those with strong normative commitment because they feel they ought to do so. (Allen and Meyer 1990).

\subsection{Job Satisfaction and Organizational Commitment}

In the past three decades, bundles of researches were conducted aiming to investigate the relationship between job satisfaction and organizational commitment in which their result shows controversial. Despite of the variety in degree and causal relationship on job satisfaction and organizational commitment, (Bateman and Strasser 1984)(Ting 1996)(Morrow 1983, Williams and Hazer 1986, Mathieu and Zajac 1990), (Al-Aameri 2000), (Al-Hussami 2008), (Çelik 2008), (Azeem 2010), (Suma and Lesha 2013), (Getahun, Sims et al. 2008)(Crossman and Abou-Zaki 2003); (Ravindranath and Joy), (Kaplan, Ogut et al. 2012), (Griffith-Kranenburg 2013) and (Eliyana, Yusuf et al. 2012) found that there is a positive relationship between job satisfaction and organizational commitment. Concerning the course of influence, whether job satisfaction results organizational commitment or commitment brings job satisfaction is still in dilemma with no consensus in either way. For simplicity, (Bateman and Strasser 1984) and (Ting 1996) advocated that job satisfaction succeeds organizational commitment and added that once employees joined the organization, it's their commitment precedes their attitude towards job satisfaction. quite the opposite, researches such as (Farkas and Tetrick 1989) and (Lincoln and Kalleberg 1992) argued that satisfaction precedes commitment. Apart from the above contradicting arguments, a previous study by (Curry, Wakefield et al. 1986) and a recent study by (Norizan 2012) shows that there is no significant relationship between organizational commitment and job satisfaction meaning that whether employees are committed or not committed with their current job, it does not affect the level of their job satisfaction and therefore can be handled separately.

H7: Control variables will have impact on the relationship b/n JSF and Affective commitment.

H8:Control variables will have impact on the relationship $b / n$ JSF and Continuance commitment.

H9:Control variables will have impact on the relationship b/n JSF and Normative 


\section{Macrothink

commitment.

\section{Research Methodology}

\subsection{Research Instrument}

Respondents' job satisfaction was assessed using Job Satisfaction Survey (JSS) developed by (Spector 1994) in which (Van Saane, Sluiter et al. 2003) study confirmed that JSS met the quality criteria for reliability and validity with internal consistency of .91. In this research, 24 items out of the total 36 items of JSS were used in which each organizational variable; Pay, Promotion, Supervision, Co-workers, Nature of work and communication have 4 items each. Respondents' organizational commitment is assessed using 18 items of Organizational Commitment Questionnaire (OCQ) developed by (Meyer and Allen 1991). Those items include 6 items for eachaffective, continuance and normative commitment. 5-points Likert scale was used to measure the responses concerning their satisfaction level. (1=strongly disagree, $2=$ disagree $3=$ neutral $4=$ agree $5=$ strongly agree).Moreover, age, gender, marital status and work experience were used as control variables.

\subsection{Date Collection Procedure}

To come up with more fruitful results and make the research more comprehensive, the research included both qualitative and quantitative data. The sources of data employed in this research study are both primary and secondary data. Extensive review of related literatures is at the center of the research methods employed. Primary data was gathered throughout a self-structured questionnaire from the basic employees on the selected star hotels in Eritrea. 242 complete questionnaires were collected and used for analysis.

\section{Result and Discussion}

\subsection{Reliability Test}

According (Joppe 2000), reliability defined as the extent to which results are consistent over time and an accurate representation of the total population under study is referred to as reliability and if the results of a study can be reproduced under a similar methodology, then the research instrument is considered to be reliable. To confirm the internal reliability of the instruments used, a Cronbach alpha co-efficient was calculated. The instrument used to measure each variable in this study is reliable and good with reliability scales ranged from 0.801 (Communication) to 0.979 (pay). Table 1 below shows the result of internal reliability calculations. 


\begin{tabular}{|l|l|l|}
\hline Variables & N of Items & Cronbach's Alpha \\
\hline Pay & 4 & .979 \\
\hline Promotion & 4 & .885 \\
\hline Supervision & 4 & .826 \\
\hline Co-workers & 4 & .821 \\
\hline Nature of work & 4 & .885 \\
\hline Communication & 4 & .801 \\
\hline Total Job satisfaction & $\mathbf{2 4}$ & $\mathbf{. 8 9 6}$ \\
\hline Affective commitment & 6 & .856 \\
\hline Continuance Commitment & 6 & .908 \\
\hline Normative Commitment & 6 & .878 \\
\hline Total Organizational Commitment & $\mathbf{1 8}$ & $\mathbf{. 9 3 2}$ \\
\hline
\end{tabular}

Table 1: Reliability Co-efficient

\subsection{Descriptive Statistics}

The descriptive statistics results show that the majority $181(74.8 \%)$ of the respondents were female while $61(25.2 \%)$ were male. $67(27.7 \%)$ of the respondents were between the ages of 26-30, followed by, 61 (25.2\%) were between the age of 31-40 years, 41 (16.9\%) were between 21 to 25 years, $36(14.9 \%)$ were between 36 to 40 years, 24 (9.9\%) were above 40 and respondents under 20 years constitute $13(5.4 \%)$. The results indicate that $139(57.4 \% 0$ of the respondents were married while $66(27.3 \%)$ were singles. And the third group characterized by -ther" constitutes 37 (15.3\%). The results demonstrated that $79(32.6 \%)$ of the respondents had 1 to 3 years of experiences with their current hotel, followed by, 66 $(27.3 \%)$ with below 1 year, $37(15.3 \%)$ the respondents had 4 to 6 years of experience, 36 $(14.9 \%)$ with 7 to 9 years and finally respondents who had more than 10 years of work experience accounted for $24(9.9 \%)$. 
4.3Relationship between Job satisfaction Factors and Components of Organizational Commitment

\begin{tabular}{|l|l|l|l|}
\hline $\begin{array}{l}\text { Job satisfaction } \\
\text { factors }\end{array}$ & $\begin{array}{l}\text { Affective } \\
\text { Commitment }\end{array}$ & $\begin{array}{l}\text { Continuance } \\
\text { Commitment }\end{array}$ & $\begin{array}{l}\text { Normative } \\
\text { Commitment }\end{array}$ \\
\hline Pay & $0.447 * *$ & $0.451^{* *}$ & $0.461 * *$ \\
\hline Promotion & $0.398 * *$ & $0.359 * *$ & $0.304 * *$ \\
\hline Nature of work & $0.324 * *$ & $0.285^{* *}$ & $0.190 * *$ \\
\hline Communication & $0.318^{* *}$ & $0.262 * *$ & $0.228 * *$ \\
\hline
\end{tabular}

**. Correlation is significant at the 0.01 level (2-tailed).

Table 2: Correlations results: Job satisfaction factors and components of Organizational commitment.

According to the Pearson correlation analysis result exposed in table 2 above, Correlation analysis was done to identify the relationship between pay, promotion, supervision, co-workers, nature of work and communication against affective, continuance and normative commitment. The result indicates that there is significant positive relationship between pay, promotion, nature of work and communication with each affective, continuance and normative commitment and hence, H1, H2, H5, and H6 are accepted. On the Contrary, this research found that satisfaction with supervision and co-workers to have no relationship with employees AC, CC and $\mathrm{NC}$ and hereafter $\mathrm{H3}$ and $\mathbf{H 4}$ are rejected.

\subsection{The Impact of Control Variables on the Relationship b/n JSF and Components of Organizational Commitment.}

To identify whether control variables have impact on the relationship $b / n$ job satisfaction factors and components of organizational commitment, a hierarchical stepwise multiple regressions was examined.

In the first step affective commitment was regressed on all the control variables (gender, age, marital status, work experience, hotel category and work location) and the model was insignificant with $p>.05$, this mean that the control variables alone can't predict the basic employees' affective commitment. In the second step with stepwise regression, the JSF were added in to the model and the model is significant at $p<.05$ and $\mathrm{R}^{2}=0.282$. After controlling the respondents' age, gender, marital status, work experience and working hotel category, the result proved that pay with $\beta=0.311$, promotion with $\beta=0.178$, supervision with $\beta=0.313$ and communication with $\beta=0.134$ to have significant relationship with affective 
commitment. This result advocated that if the star hotels management intended to increase the basic employees' affective commitment, then the employees' satisfaction with pay, promotion, supervision and communication should be enhanced. On the other hand, satisfaction with co-workers and nature of work found to be insignificant to predict the employees' affective commitment and hence $\mathbf{H 7}$ is partially supported.

\begin{tabular}{|l|l|l|l|l|}
\hline \multicolumn{4}{|l|}{ Affective commitment } \\
\hline Variable & $\mathbf{R}^{2}$ & $\mathbf{R}^{2}$ change & F & Beta \\
\hline Step 1 & .019 & .019 & .890 & \\
\hline Control variables & & & & \\
\hline Step 2 & .282 & .263 & $10.12^{*}$ & \\
\hline Pay & & & & $.311^{*}$ \\
\hline Promotion & & & $.178^{*}$ \\
\hline Supervision & & & $.313^{*}$ \\
\hline Communication & & & & $.134^{*}$ \\
\hline
\end{tabular}

Table 3: Hierarchical stepwise regression: Predicting affective commitment from control variables and JSF

To identify the impact of the control variables on the relationship between the JSF and continuance commitment, first continuance commitment was regressed on the control variables and the model was insignificant with $p>.05$, this mean that the control variables alone can't predict the basic employees' continuance commitment. Next, the JSF were added in to the model and the model is significant at $\boldsymbol{p}<.05$ and $\mathrm{R}^{2}=0.226$. After controlling the respondents' age, gender, marital status, work experience and working hotel category, the result proved that only pay with $\beta=0.364$ and promotion with $\beta=0.169$ have significant relationship with continuance commitment. This result illustrated that to increases the basic employees' continuance commitment, the employees' satisfaction with pay and promotion should be considered as a key factors. More over the result shows that, satisfaction with supervision, co-workers, nature of work and communication contributes nothing to the basic employees' continuance commitment and hence H8is partially supported. 


\begin{tabular}{|l|l|l|l|l|}
\hline \multicolumn{4}{|l|}{ Continuance Commitment } \\
\hline Variable & $\mathbf{R}^{2}$ & $\mathbf{R}^{2}$ change & F & Beta \\
\hline Step 1 & .001 & .001 & .064 & \\
\hline Control variables & & & & \\
\hline Step 2 & .226 & .225 & $9.75^{*}$ & \\
\hline Pay & & & & $.364^{*}$ \\
\hline Promotion & & & & $.169^{*}$ \\
\hline
\end{tabular}

Table 4: Hierarchical stepwise regression: Predicting continuance commitment from control variables and JSF

To recognize which among the JSF including the control variables have relationship with normative commitment, hierarchical stepwise regression was done, first normative commitment was regressed on the control variables and the model was insignificant with $p>.05$, this mean that the control variables alone can't predict the basic employees' normative commitment. Following, the JSF were added in to the model and the model is significant at $\boldsymbol{p}<.05$ and $\mathrm{R}^{2}=0.215$. After controlling the respondents' age, gender, marital status, work experience and working hotel category, the result illustrated that only pay with $\beta$ $=0.465$ possess significant relationship with normative commitment. This result demonstrates that, the basic employees' normative commitment can be predicted by the employees' satisfaction with pay. Furthermore the result shows that, satisfaction with promotion, supervision, co-workers, nature of work and communication contributes nothing to the basic employees' normative commitment and hence H9is partially supported.

\begin{tabular}{|l|l|l|l|l|}
\hline \multicolumn{4}{|l|}{ Normative commitment } \\
\hline Variable & $\mathbf{R}^{2}$ & $\mathbf{R}^{2}$ change & $\mathbf{F}$ & Beta \\
\hline Step 1 & .000 & .000 & .023 & \\
\hline Control variables & & & & \\
\hline Step 2 & .215 & .215 & $10.72^{*}$ & \\
\hline Pay & & & & $.465^{*}$ \\
\hline
\end{tabular}

Table 5: Hierarchical stepwise regression: Predicting normative commitment from 


\section{control variables and JSF}

2015, Vol. 5, No. 4

To sum up, though the correlation analysis illustrated that pay, promotion, nature of work and communication can contributes to the basic employees' affective, continuance and normative commitment, but with the inclusion of the control variables the result appeared differently. On the presence of control variables, pay, promotion, supervision and communication can contributes to the employees' affective commitment, pay and promotion can contributes to the employees" continuance commitment and only pay can contributes to the employees' normative commitment.

For employees in developing countries like Eritrea, in which their daily life is supported by the pay from their organization, pay appeared to be the fundamental factor in determining the employees' affective, continuance and normative commitment. Therefore, planning for a fair pay system can help the organization to build their employees commitment toward their organization. In addition, an encourage-able and supportive supervision style can contributes to the employees' commitment. A sound leadership can encourage employees to work hand, promote team harmony and increases employees' commitment through the establishment of healthy environment in the organization. Communication dimensions such as communicative activities, communication information, relationships, channels, and climate in the organization also influence the employees' commitment. Therefore, this research reminds the management of star hotels to pay attention on the overall dimension of communication and improve them according to the policies of the organization and needs of their employees.

\section{Conclusion}

The main objective of this study is to investigate how factors of job satisfaction (pay, promotion, supervision, coworkers, nature of work and communication) affect employees' affective, continuance and normative commitment. Besides, the research also tried to identify the impact of control variables on the relationship between the JSF and components of organizational commitment. According to the Pearson correlation analysis result, Correlation analysis was done to identify the relationship between pay, promotion, supervision, co-workers, nature of work and communication against affective, continuance and normative commitment. The result indicates that there is significant positive relationship between pay, promotion, nature of work and communication with each affective, continuance and normative commitment. Though the correlation analysis illustrated that pay, promotion, nature of work and communication can contributes to the basic employees' affective, continuance and normative commitment, but with the inclusion of the control variables the result become different. On the presence of control variables, pay, promotion, supervision and communication can contributes to the employees' affective commitment, pay and promotion can contributes to the employees" continuance commitment and only pay can contributes to the employees' normative commitment.

\section{References}

Al-Aameri, A. S. (2000). "Job satisfaction and organizational commitment for nurses." Saudi 
Medical Journal21(6): 531-535.

Al-Hussami, M. (2008). "A study of nurses' job satisfaction: the relationship to organizational commitment, perceived organizational support, transactional leadership, transformational leadership, and level of education." European Journal of Scientific Research22(2): 286-295.

Allen, N. J. and J. P. Meyer (1990). "The measurement and antecedents of affective, continuance and normative commitment to the organization." Journal of occupational psychology63(1): 1-18.

Alshitri, K. I. (2013). "An investigation of factors affecting job satisfaction among R\&D center employees in Saudi Arabia." Journal of Human Resources Management Research2013: $1-10$.

Armstrong, M. and S. Taylor (2014). Armstrong's handbook of human resource management practice, Kogan Page Publishers.

Azeem, S. M. (2010). "Job satisfaction and organizational commitment among employees in the Sultanate of Oman." Psychology1(04): 295.

Bakotić, D. and T. Babić (2013). "Relationship between Working Conditions and Job Satisfaction: The Case of Croatian Shipbuilding Company." International Journal of Business and Social Science4(2): 206-213.

Barak, M. E. M., et al. (2009). "The impact of supervision on worker outcomes: a meta-analysis." Social Service Review83(1): 3-32.

Bateman, T. S. and S. Strasser (1984). "A longitudinal analysis of the antecedents of organizational commitment." Academy of management journal27(1): 95-112.

Bhamani, S. "Factors Determining Job Satisfaction of Early Childhood Teachers."

Çelik, C. (2008). "Relationship of organizational commitment and job satisfaction: A field study of tax office employees."

Chughtai, A. A. and S. Zafar (2006). "Antecedents and consequences of organizational commitment among Pakistani university teachers."

Cohen-Charash, Y. and P. E. Spector (2001). "The role of justice in organizations: A meta-analysis." Organizational behavior and human decision processes86(2): 278-321.

Crossman, A. and B. Abou-Zaki (2003). "Job satisfaction and employee performance of Lebanese banking staff." Journal of Managerial Psychology18(4): 368-376.

Curry, J. P., et al. (1986). "On the causal ordering of job satisfaction and organizational commitment." Academy of management journal29(4): 847-858.

Danish, R. Q. and A. Usman (2010). "Impact of reward and recognition on job satisfaction and motivation: An empirical study from Pakistan." International journal of business and management5(2): p159. 


\section{Macrothink}

International Journal of Human Resource Studies ISSN 2162-3058 2015, Vol. 5, No. 4

Drakopoulos, S. A. and A. Grimani (2011). "The relationship between absence from work and job satisfaction: Greece and UK comparisons."

Eliyana, A., et al. (2012). "The Influence of Employee's Job Satisfaction Factors on Organizational Commitment."

Farkas, A. J. and L. E. Tetrick (1989). "A three-wave longitudinal analysis of the causal ordering of satisfaction and commitment on turnover decisions." Journal of applied psychology74(6): 855 .

Gaertner, K. N. and S. D. Nollen (1989). "Career experiences, perceptions of employment practices, and psychological commitment to the organization." Human relations42(11): 975-991.

Getahun, S., et al. (2008). "Job satisfaction and organizational commitment among probation and parole officers: A case study." Professional Issues in Criminal Justice3(1): 1-16.

Ghazzawi, I. (2008). "Job satisfaction antecedents and consequences: A new conceptual framework and research agenda." The Business Review11(2): 1-10.

Griffith-Kranenburg, D. (2013). "THE EFFECT OF ORGANIZATIONAL CULTURE AND LEADERSHIP STYLE ON ORGANIZATIONAL COMMITMENT WITHIN SMES IN SURINAME, WITH JOB SATISFACTION AS A MEDIATOR."

Hom, P. W. and R. W. Griffeth (1995). Employee turnover, South-Western Pub.

Joppe, M. (2000). "The research process." Retrieved February25: 1998.

Kabir, M. N. and M. M. Parvin (2011). "Factors affecting employee job satisfaction of pharmaceutical sector." Australian Journal of Business and Management Research1(9): 113-123.

Kantor, R. L. (2013). Pay satisfaction, organisational commitment, voluntary turnover intention, and attitudes to money in a South African context.

Kaplan, M., et al. (2012). "The relationship between job satisfaction and organizational commitment: The case of hospital employees." World4(1): 22-29.

Kosteas, V. D. (2011). "Job satisfaction and promotions." Industrial Relations: A Journal of Economy and Society50(1): 174-194.

Lincoln, J. R. and A. L. Kalleberg (1992). Culture, control, and commitment: A study of work organization and work attitudes in the United States and Japan, CUP Archive.

Lumley, E., et al. (2011). "Exploring the job satisfaction and organisational commitment of employees in the information technology environment." Southern African Business Review15(1): 100-118.

Malik, M. E., et al. (2010). "Job satisfaction and organizational commitment of university teachers in public sector of Pakistan." International Journal of Business and Management5(6): p17. 
Mathieu, J. E. and D. M. Zajac (1990). "A review and meta-analysis of the antecedents, correlates, and consequences of organizational commitment." Psychological bulletin108(2): 171.

Meyer, J. P. and N. J. Allen (1991). "A three-component conceptualization of organizational commitment." Human resource management review1(1): 61-89.

Mohd, A. (2003). Nasurdin, Ramayah T., Mohamad Abdullah Hemdi and Seow Lee Voon (2003) Job satisfaction and turnover intentions: A Study among Academicians". The Proceedings of the 5th Asian Academy of Management Conference,-Challenges of Globalized Business: The Asian Perspective", 10th-13th September.

Morrow, P. C. (1983). "Concept redundancy in organizational research: The case of work commitment." Academy of management Review8(3): 486-500.

Mustapha, N. and Z. C. Zakaria (2013). "The effect of promotion opportunity in influencing job satisfaction among academics in higher public institutions in malaysia." International Journal of Academic Research in Business and Social Sciences3(3): 20-26.

Norizan, I. (2012). Organizational commitment and job satisfaction among staff of higher learning education institutions in Kelantan, Universiti Utara Malaysia.

O'Reilly III, C. A. (1989). "Corporations, Culture and Commitment: Motivation and Social Control." California Management Review 31: 9-25.

Ravindranath, S. and J. Joy "Exploring the Relationship between Job Satisfaction and Organizational Commitment of Nurses."

Saleem, S., et al. (2013). "Determinants of job satisfaction among employees of banking industry at Bahawalpur." Journal of Emerging Issues in Economics, Finance and Banking1(2): 150-162.

Spector, P. E. (1994). "Job satisfaction survey." Tampa, Florida: Department of Psychology, University of South Florida.

Spector, P. E. (1997). Job satisfaction: Application, assessment, causes, and consequences, Sage.

Suma, S. and J. Lesha (2013). "Job satisfaction and organizational commitment: The case of Shkodra municipality." European Scientific Journal9(17).

Sypniewska, B. (2014). "Evaluation of Factors Influencing Job Satisfaction." Contemporary Economics8(1): 57-72.

Tang, T. L.-P. and R. K. Chiu (2003). "Income, money ethic, pay satisfaction, commitment, and unethical behavior: Is the love of money the root of evil for Hong Kong employees?" Journal of Business Ethics46(1): 13-30.

Teclemichael Tessema, M. and J. L. Soeters (2006). "Challenges and prospects of HRM in developing countries: testing the HRM-performance link in the Eritrean civil service." The 


\section{Macrothink \\ International Journal of Human Resource Studies \\ ISSN 2162-3058 2015, Vol. 5, No. 4}

international journal of human resource management17(1): 86-105.

Ting, Y. (1996). "Analysis of job satisfaction of the federal white-collar work force: Findings from the Survey of Federal Employees." The American Review of Public Administration26(4): 439-456.

Tourani, A. and R. Sadegh (2012). Effect of employees' communication and participation on employees' job satisfaction: An empirical study on airline companies in Iran. International Conference on Economics, Trade, and Development.

Van Saane, N., et al. (2003). "Reliability and validity of instruments measuring job satisfaction - a systematic review." Occupational medicine53(3): 191-200.

Voon, M. L., et al. (2011). "The influence of leadership styles on employees' job satisfaction in public sector organizations in Malaysia." International Journal of Business, Management and Social Sciences2(1): 24-32.

Warsi, S., et al. (2009). "Study on relationship between organizational commitment and its determinants among private sector employees of Pakistan." International Review of Business Research Papers5(3): 399-410.

Williams, L. J. and J. T. Hazer (1986). "Antecedents and consequences of satisfaction and commitment in turnover models: A reanalysis using latent variable structural equation methods." Journal of applied psychology71(2): 219.

YAU, A. Z. (2013). The impact of communication satisfaction and emotional exhaustion on organizational commitment, UTAR. 